\title{
Sex ratio distortion in Acraea encedon (Lepidoptera: Nymphalidae) is caused by a male-killing bacterium
}

\author{
FRANCIS M. J IGGINS*†, GREGORY D. D. HURST + \& MICHAEL E. N. MAJ ERUS $\dagger$ \\ $\dagger$ Department of Genetics, University of Cambridge, Downing Street, Cambridge CB2 3EH and ¥Department of \\ Biology, Wolfson House, 4 Stephenson Way, London NW1 2HE, U.K.
}

\begin{abstract}
Females of the butterfly Acraea encedon produce either entirely female offspring or males and females in an almost 1:1 sex ratio. The sex ratio produced is maternally inherited and was previously attributed to sex chromosome meiotic drive. We report that all-female lineages are associated with low egg-hatching rates and that the trait is cured by antibiotic treatment. We thus reject the hypothesis that this sex ratio bias is caused by a meiotically driven sex chromosome and, instead, propose that it is associated with a maternally inherited bacterium that kills males.
\end{abstract}

Keywords: Acraea encedon, male killing, meiotic drive, sex ratio.

\section{Introduction}

An allele is said to show meiotic drive when it 'cheats' during meiosis and is represented in more than $50 \%$ of gametes. The drive allele can spread through a population even if the cost to the individual of carrying this genomic parasite is considerable. If a drive allele is found on a sex chromosome, it will result in distortion of the sex ratio. Meiotic drive has been postulated to be an important force during a range of evolutionary changes, including speciation (Frank, 1991; Hurst \& Pomiankowski, 1991), the evolution of crossing-over (Haig \& Grafen, 1991) and the evolution of sex-determining mechanisms (Bull, 1979). For theories on the evolutionary importance of meiotic drive to have general applicability, it is first necessary to demonstrate that meiotic drive is a common phenomenon and that it occurs in a diverse range of taxa. To date, there is no definitive record of sex chromosome or autosomal meiotic drive in arthropods outside of the Diptera (see references in Hurst \& Pomiankowski, 1991). The aim of this study was to investigate whether female-biased sex ratios recorded in the butterfly Acraea encedon (L.) are the result of sex chromosome meiotic drive, as has been proposed previously.

\footnotetext{
*Correspondence. E-mail: fmj1001@mole.bio.cam.ac.uk
}

Poulton (1914) first reported that some females of the African butterfly Acraea encedon produce only daughters, whereas others produce both sons and daughters. The sex ratio trait is maternally inherited (Owen, 1970). That this is a distortion of the sex ratio and not a change in sexuality to parthenogenesis is suggested by the finding that virgin females lay infertile eggs (Chanter \& Owen, 1972). In butterflies, both the $\mathrm{W}$ chromosome (females are the heterogametic sex and carry ZW chromosomes) and the cytoplasmic genes (mitochondria and any intracellular endosymbionts) are maternally inherited and are thus selected to maximize the production and survival of female offspring. Chanter \& Owen (1972) concluded that all-female broods were caused by a driving $\mathrm{W}$ chromosome distorting the primary sex ratio. However, Chanter \& Owen's (1972) results distinguished neither which maternally inherited gene was causing the all-female broods nor whether all-female broods resulted from primary sex ratio distortion or from the death of male embryos or larvae. Male death could still result in all-female and normal sex ratio broods producing similar numbers of adults (as found by Chanter \& Owen, 1972) if larval survival in all-female broods increases because of the benefits of cannibalizing dead brothers or through reduced competition in the absence of male siblings. The latter is likely, as survival is often strongly density-dependent in the laboratory. 


\section{Methods}

In May 1997, adult Acraea encedon samples were collected from a single colony at Kagolomolo on the shores of Lake Victoria in Uganda, which was studied previously by Owen \& Chanter (1969). The butterflies were taken to Watamu on the coast of Kenya, where the females laid eggs upon the host plant, Commelina benghalensis. Eggs and newly emerged larvae were counted to give egg hatch rates. Large clutches were photographed and counted at a later date. Up to five females were taken from each brood, mated and their egg hatch rates recorded. Up to three broods from each matriline were reared to adulthood, and the rest were discarded after hatching.

Adult females or larvae were treated with three antibiotics that had previously been shown to cure insects infected with cytoplasmic bacteria (Stouthamer et al., 1990). The concentrations used were the highest the butterflies would tolerate without refusing to feed. Fifth instar larvae were taken from some of the $\mathrm{F}_{1}$ broods and placed on plants of $C$. benghalensis whose leaves had been dipped in a $5 \%(\mathrm{w} / \mathrm{v})$ aqueous solution of tetracycline hydrochloride or a $2 \%(\mathrm{w} / \mathrm{v})$ aqueous solution of sulphamethoxazole; a control group was fed on untreated plants. Caterpillars that refused to eat or pupated in under 2 days were discarded. Adult $\mathrm{F}_{1}$ females were fed $10 \%$ $(\mathrm{w} / \mathrm{v})$ rifampicin in sugar solution daily for 6 days; a control group was fed on sugar solution alone.

\section{Results}

Among broods reared from wild females $(n=35)$, $86 \%$ produced only female offspring, whereas the remaining broods contained both males and females (Table 1). As seen from the sex ratio of the $F_{1}$ crosses, the trait was inherited by all the tested females, which is consistent with the maternal inheritance of sex ratio found by Chanter \& Owen (1972). The parental generation of broods containing males (Table $1 \mathrm{~b}$ ) was significantly female biased $\left(\chi_{1}^{2}=10.13 ; P<0.01\right)$, but the sex ratio of the $\mathrm{F}_{1}$ generation did not differ significantly from 1:1 $\left(\chi_{1}^{2}=0.80 ; \mathrm{NS}\right)$. The cause of this sex ratio bias is not known.

The hatch rates of broods from all-female matrilines and normal sex ratio matrilines are significantly different (Mann-Whitney $U$-test: $n_{1}=41, n_{2}=152$; $U=1634 ; P<0.0001)$; this result is still significant if only broods reared to adulthood are included (Mann-Whitney $U$-test: $n_{1}=11, n_{2}=43 ; U=69.5$; $P<0.0005)$. The hatch rates of broods from
Table 1 Sex ratios produced by wild (parental) female Acraea encedon and in the subsequent $\left(\mathrm{F}_{1}\right)$ generation

\begin{tabular}{|c|c|c|c|c|}
\hline \multirow[b]{2}{*}{$\begin{array}{l}\text { Matriline } \\
\text { number }\end{array}$} & \multicolumn{2}{|c|}{ Parental females } & \multicolumn{2}{|c|}{$\mathrm{F}_{1}$} \\
\hline & $\begin{array}{c}\text { Male } \\
\text { progeny }\end{array}$ & $\begin{array}{l}\text { Female } \\
\text { progeny }\end{array}$ & $\begin{array}{c}\text { Male } \\
\text { progeny }\end{array}$ & $\begin{array}{l}\text { Female } \\
\text { progeny }\end{array}$ \\
\hline \multicolumn{5}{|c|}{ (a) All-female broods } \\
\hline 1 & 0 & 52 & 0 & 64 \\
\hline 2 & 0 & 62 & $\begin{array}{l}0 \\
0\end{array}$ & $\begin{array}{l}97 \\
80\end{array}$ \\
\hline 3 & 0 & 70 & 0 & 20 \\
\hline 4 & 0 & 48 & 0 & 81 \\
\hline 5 & 0 & 31 & 0 & 67 \\
\hline 6 & 0 & 52 & 0 & 104 \\
\hline 10 & 0 & 15 & 0 & 58 \\
\hline 11 & 0 & 25 & 0 & 80 \\
\hline 15 & 0 & 5 & 0 & 49 \\
\hline 16 & 0 & 8 & 0 & 19 \\
\hline 17 & 0 & 3 & 0 & 3 \\
\hline 26 & 0 & 5 & & \\
\hline 30 & 0 & 38 & 0 & 6 \\
\hline 31 & 0 & 19 & 0 & 4 \\
\hline 33 & 0 & 6 & & \\
\hline 35 & 0 & 35 & & \\
\hline 37 & 0 & 34 & 0 & 4 \\
\hline 38 & 0 & 28 & & \\
\hline 39 & 0 & 17 & & \\
\hline 40 & 0 & 45 & 0 & 1 \\
\hline 41 & 0 & 29 & & \\
\hline 42 & 0 & 41 & & \\
\hline 44 & 0 & 32 & & \\
\hline 45 & 0 & 9 & 0 & 3 \\
\hline 49 & 0 & 11 & & \\
\hline 50 & 0 & 27 & & \\
\hline 55 & 0 & 11 & & \\
\hline 117 & 0 & 9 & 0 & 15 \\
\hline 118 & 0 & 20 & & \\
\hline 119 & 0 & 8 & & \\
\hline \multicolumn{5}{|c|}{ (b) Normal sex ratio broods } \\
\hline \multirow[t]{2}{*}{7} & 4 & 12 & 5 & 3 \\
\hline & & & 13 & 19 \\
\hline \multirow[t]{3}{*}{8} & 4 & 15 & 27 & 36 \\
\hline & & & 27 & 38 \\
\hline & & & 28 & 23 \\
\hline \multirow[t]{2}{*}{19} & 2 & 4 & 4 & 2 \\
\hline & & & 15 & 8 \\
\hline 34 & 12 & 22 & & \\
\hline 58 & 5 & 3 & & \\
\hline
\end{tabular}

Matrilines from which five or fewer individuals were reared over both generations are not shown. The eight largest normal broods (Table 1b) have heterogeneous sex ratios $\left(\chi_{7}^{2}=14.4 ; P<0.05\right)$. 
all-female matrilines were never significantly greater than $50 \%$, whereas broods from females in normal sex ratio matrilines had hatch rates of up to $100 \%$ (Fig. 1).

In all-female broods, there were large numbers of unhatched eggs visible when they had not been cannibalized. These eggs were black because of the tanned head capsule of a fully developed larval embryo. Black unhatched eggs were only rarely observed in normal sex ratio broods. Figure 1 also shows that many broods had very low hatch rates. Both normal and all-female broods with very low hatch rates were characterized by the presence of yellow unhatched eggs, presumed to be infertile. Yellow unhatched eggs were observed in similar proportions of all-female and normal broods (13 of 43 normal broods; 46 of 158 all-female broods; $\chi_{1}^{2}=0.02$; NS). Often, one region of a brood did not hatch and the eggs remained yellow; this contrasts with the even distribution of black unhatched eggs in all-female broods. Sib-matings did not have significantly lower hatch rates than outcrossed broods in

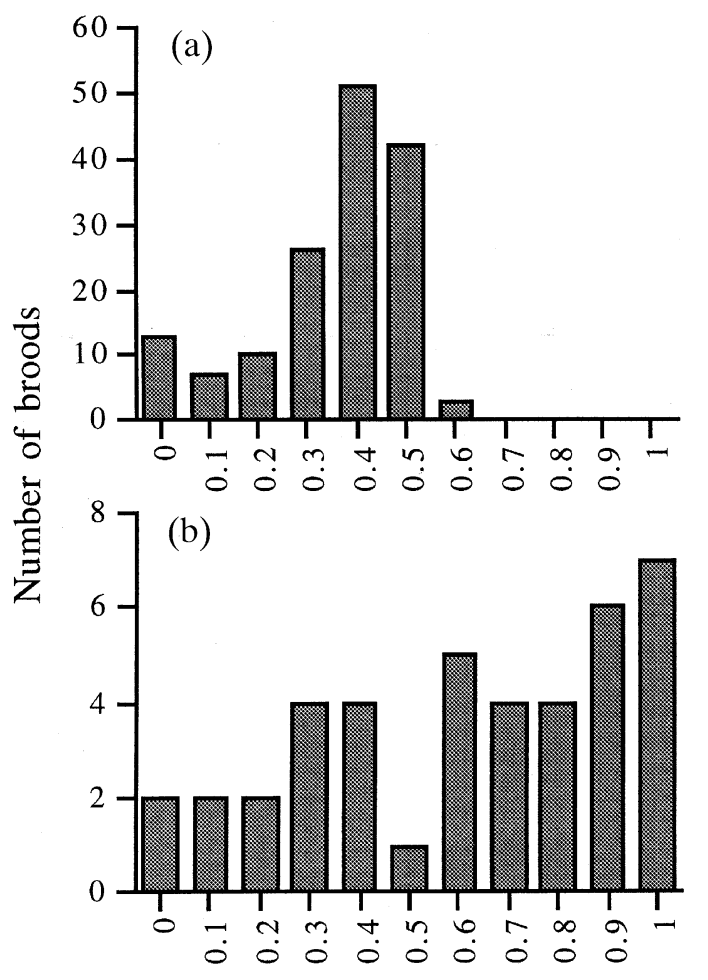

Egg hatch rate

Fig. 1 Histogram of egg hatch rates from (a) all-female matrilines and (b) normal sex ratio matrilines of Acraea encedon. Brood sizes range from 22 to 470 eggs. Where one butterfly laid more than one clutch of eggs, they were combined as a single brood.
Table 2 Sex ratios produced by female Acraea encedon from all-female matrilines treated with antibiotics

\begin{tabular}{lccc}
\hline Antibiotic & Matriline & Males & Females \\
\hline Sulphamethoxazole & 3 & 1 & 2 \\
Sulphamethoxazole & 3 & 7 & 6 \\
Sulphamethoxazole & 4 & 9 & 13 \\
Sulphamethoxazole & 5 & 12 & 15 \\
Tetracycline & 11 & 1 & 2 \\
Rifampicin & 1 & 0 & 38 \\
Rifampicin & 10 & 0 & 15 \\
Rifampicin & 5 & 0 & 5 \\
Rifampicin & 6 & 0 & 7 \\
\hline
\end{tabular}

All the females are taken from the parental generation shown in Table 1. Untreated controls are the $F_{1}$ generation of the appropriate matriline shown in Table 1.

normal matrilines (data not shown, Mann-Whitney $U$-test: $n_{1}=15, n_{2}=20 ; U=131.5 ; \mathrm{NS}$ ).

Table 2 shows the sex ratios produced by females from all-female matrilines that had been treated with antibiotics. Males were produced by females that had been treated with sulphamethoxazole or tetracycline as caterpillars. No successful treatments of normal sex ratio matrilines were completed to control for the endogenous effects of the antibiotic on sex ratio, although none is likely. The antibiotic rifampicin failed to cure the trait when fed to adults.

\section{Discussion}

Acraea encedon females produce either entirely female offspring or approximately equal numbers of males and females. This trait has now been found at high frequencies across Africa, from Sierra Leone to Tanzania, $6000 \mathrm{~km}$ to the east (Table 3). The sex ratio produced is maternally inherited, suggesting that all-female broods are caused by a selfish genetic element biasing sex allocation to enhance its own transmission. The hatch rate of broods from all-female matrilines is never significantly greater than $50 \%$, whereas normal sex ratio lines have hatch rates of up to $100 \%$. All-female broods in $A$. encedon are thus the result of the death of male embryos and are not caused by $\mathrm{W}$ chromosome meiotic drive distorting the primary sex ratio, as previously thought (Chanter \& Owen, 1972). The fact that antibiotics cured all-female matrilines strongly suggests that the cause of all-female broods is a bacterium.

Sex chromosome meiotic drive has not been demonstrated conclusively in any arthropod taxa 
Table 3 The frequency of all-female broods of Acraea encedon produced by wild females or wild-collected broods in the current and previous studies

\begin{tabular}{lccl}
\hline Country & $\begin{array}{c}\text { Proportion } \\
\text { all-female }\end{array}$ & $\begin{array}{c}\text { Broods } \\
\text { reared }\end{array}$ & \multicolumn{1}{c}{ Reference } \\
\hline Tanzania & 0.73 & 15 & Owen \& Smith (1991) \\
Sierra Leone & 0.95 & 61 & Chanter \& Owen (1972) \\
Ghana & 0.20 & 10 & Chanter \& Owen (1972) \\
Ghana & 0.61 & 72 & Gordon (1982) \\
Ghana & 0.60 & 20 & $\begin{array}{l}\text { D. F. Owen \& C. A. Clarke, unpublished } \\
\text { data from 1982 }\end{array}$ \\
Nigeria & 0.70 & 26 & Poulton (1914) \\
Uganda & 0.77 & 13 & Owen (1965); Chanter \& Owen (1972) \\
Uganda & 0.86 & 35 & This study \\
\hline
\end{tabular}

outside of the Diptera (see list in Hurst \& Pomiankowski, 1991). Sex chromosome meiotic drive was suspected to cause female-biased sex ratios in two species of butterfly, Acraea encedon and Danaus chrysippus, but the death of male embryos is now known to be the cause of sex ratio distortion in both these species (this paper and Owen \& Smith, 1991).

The killing of males is, at worst, selectively neutral to a maternally inherited bacterium. The spread of male-killing bacteria is thought to result either from male-killing enhancing horizontal transmission of the parasite or through the death of males benefiting female siblings carrying clonal relatives of the bacterium (Hurst, 1991). Horizontal transmission has never been observed under laboratory conditions and, were this the selective advantage of malekilling, theory suggests that males would be more likely to be killed during late larval instars (Hurst, 1991).

Male death may benefit female siblings by preventing inbreeding. Owen et al. (1973) calculated from the population sex ratio that, in most femalebiased populations encountered, the majority of females must remain unmated. This was confirmed in the field, where most wild females were found to be unmated, and unmated females were observed laying infertile eggs. It is unlikely under these conditions that inbreeding would be disadvantageous; inbreeding may benefit uninfected females by increasing their chances of mating. It should be noted that Owen et al.'s (1973) work confused the two species $A$. encedon and $A$. encedana Pierre, so it is not possible to tell to which species their results apply (Owen \& Smith, 1991).

The final hypothesized advantage of male-killing is that resources are reallocated from the dead males to their sisters, either through sibling canni- balism or through a reduction in competition. This possibility finds support in Chanter \& Owen's (1972) observation that females in all-female matrilines developed significantly faster than females in normal matrilines. Chanter \& Owen (1972) also found that the numbers of adults in all-female and normal broods were not significantly different, which suggests that infected females have higher egg-toadult survival. An alternative interpretation of the greater survival and growth rates of infected females is that the bacterium provides some metabolic benefit to females. Parasitic and mutualistic roles need not be mutually exclusive in endosymbionts.

In contrast to cytoplasmic genes that distort the primary sex ratio, early male-killing is found to be associated with a taxonomically diverse range of both arthropod hosts and bacterial parasites (Hurst et al., 1997). Hurst et al. (1997) hypothesized that the critical factor favouring the evolution of male-killing behaviour is a host ecology that makes antagonistic interactions between siblings or sib cannibalism likely. The finding of male-killing in $A$. encedon lends further support to the importance of host ecology in the evolution of male-killing. Acraea encedon typically lays clutches of between 50 and 300 eggs, and newly emerged larvae often cannibalize unhatched eggs. The larvae gradually disperse into smaller groups and only become solitary in the final instar. This ecology clearly provides opportunities for both egg cannibalism and sibling competition that may favour the spread of male-killers.

\section{Acknow ledgements}

This paper is dedicated to Denis Owen for his contribution to work on Acraea encedon. This research was financially supported by a BBSRC 
studentship, Sigma Xi (The Scientific Research Society) and Emmanuel College, Cambridge. Francis Jiggins was affiliated to the Kipepeo Project, National Museums of Kenya. We are grateful to Catherine Dolman, Chris Jiggins and Ian Gordon for help with rearing larvae and useful discussions. David Smith, Denis Owen and Jacques Pierre gave advice on Acraea encedon.

\section{References}

BULl, J. J. 1979. An advantage for the evolution of male haploidy and systems with similar genetic transmission. Heredity, 43, 361-381.

CHANTER, D. O. AND OWEN, D. F. 1972. The inheritance and population genetics of sex ratio in the butterfly Acraea encedon. J. Zool., 166, 363-383.

FRANK, S. A. 1991. Divergence of meiotic drive-suppression systems as an explanation for sex-biased hybrid sterility and inviability. Evolution, 45, 262-267.

GORDON, I. J. 1982. Biology of Danaus chrysippus L. (Lepidoptera, Danaidae) and its mimics in Ghana. $\mathrm{PhD}$ thesis, University of Ghana.

HAIG, D. AND GRAFEN, A. 1991. Genetic scrambling as a defence against meiotic drive. J. Theor. Biol., 153, 531-558.

HURST, G. D. D., HURST, L. D. AND MAJERUS, M. E. N. 1997. Cytoplasmic sex ratio distorters. In: O’Neill, S. L., Hoffman, A. A. and Werren, J. H. (eds) Influential
Passengers: Microbes and Invertebrate Reproduction, pp. 125-154. Oxford University Press, Oxford.

HURST, L. D. 1991. The incidences and evolution of cytoplasmic male killers. Proc. R. Soc. B, 244, 91-99.

HURST, L. D. AND POMIANKOWSKI, A. N. 1991. Causes of sex ratio bias may account for unisexual sterility in hybrids: a new explanation for Haldane's rule and related phenomena. Genetics, 128, 841-858.

OWEN, D. F. 1965. Change in sex ratio in an African butterfly. Nature, 205, 744.

OWEN, D. F. 1970. Inheritance of sex ratio in the butterfly Acraea encedon. Nature, 225, 662-663.

OWEN, D. F. AND CHANTER, D. O. 1969. Population biology of tropical African butterflies. Sex ratio and genetic variation in Acraea encedon. J. Zool., 157, 345-374.

OWEN, D. F. AND SMITH, D. A. S. 1991. All-female broods and mimetic polymorphism in Acraea encedon (L.) (Lepidoptera: Acraeidae) in Tanzania. Afr. J. Ecol., 29, 241-247.

OWEN, D. F., OWEN, J. AND CHANTER, D. O. 1973. LOW mating frequencies in an African butterfly. Nature, 244, 116-117.

POULTON, E. B. 1914. W.A. Lamborn's breeding experiments upon Acraea encedon (Linn.) in the Lagos district of West Africa, 1910-12. J. Linn. Soc. Lond., 32, $391-416$

STOUTHAMER, R., LUCK, R. F. AND HAMILTON, w. D. 1990. Antibiotics cause parthenogenetic Trichogramma (Hymenoptera/Trichogrammatidae) to revert to sex. Proc. Natl. Acad. Sci. U.S.A., 87, 2424-2427. 